\title{
The Feminisation of Belgian Local Party Politics*
}

\author{
Robin Devroe, Silvia Erzeel \& Petra Meier ${ }^{* *}$
}

\begin{abstract}
This article investigates the feminisation of local politics. Starting from the observation that the representation of women in local electoral politics lags behind the regional and federal level, and taking into account the relevance of local party branches in the recruitment and selection of candidates for elections, we examine the extent to which there is an 'internal' feminisation of local party branches and how this links to the 'external' feminisation of local electoral politics. Based on surveys among local party chairs, the article maps patterns of feminisation over time and across parties, investigates problems local branches encounter in the recruitment of candidates for local elections, and analyses the (attitudes towards the) measures taken to further the integration of women in local electoral politics. We conclude that internal and external feminisation do not always go hand in hand and that local politics continues to be a male-dominated political biotope.
\end{abstract}

Keywords: local politics, local party branches, local elections, gender quotas, Belgium.

* The three authors contributed equally to this work.

** Robin Devroe is a postdoctoral researcher in the Department of Political Sciences of Ghent University and member of the research group GASPAR. Her main research interest is the study of the political representation of diverse social groups and voting behaviour, with a specific focus on the descriptive representation of women, and she has a fascination for experimental methods. Her doctoral work (2019, Ghent University) focused on the prevalence of political gender stereotypes among Flemish voters. In the past, Robin was a visiting scholar at Texas A\&M University (2018, US). Since 2020, she has been co-convenor of the European Consortium for Political Research's (ECPR's) Group on Gender and Politics. Silvia Erzeel is Assistant Professor at the Department of Political Science, Vrije Universiteit Brussel. Her research interests include party politics, political representation, gender and intersectionality, and comparative politics. Her current research focuses on three main areas: the integration of gender equality in political parties, intersectionality and political representation in Europe, and the consequences of economic and social inequality for representative democracy. Since 2018, she has been coconvenor of the European Consortium for Political Research's (ECPR's) Standing Group on Gender and Politics. Petra Meier is Professor of Politics at the Faculty of Social Sciences, University of Antwerp. Her research focuses on the (re)presentation of gender+ in politics and policies. Late work focused on the conceptualisation of symbolic representation, how it operates and the issues at stake from an inclusive perspective. Recently, she turned to study democratic deficits in federal systems, especially Belgium, and processes of de-democratisation in general. She is particularly interested in understanding how such processes affect the demos, more particularly from a gender, an LGBTQI or an ethnic perspective, and what dynamics of marginalisation and exclusion they generate. 
In the latest 2018 Belgian local elections, 39\% of those elected were women. That is slightly more than the $36 \%$ elected in the previous local elections back in 2012. This data confirms a trend we can witness since the late 1980s for all political levels in Belgium: the share of women elected was very low for decades, increased steadily in the period 1994-2006 after the implementation of the gender quotas, and then kept increasing, though at a slower pace (see also Table 1). It is, nonetheless, interesting to observe that the number of women elected at the local level in Belgium is lower than at the other electoral levels. At the recent 2019 elections, $47 \%$ of the candidates elected on lists for the Flemish Parliament were women, $44 \%$ in the case of the Parliament of the Brussels Capital Region, $41 \%$ in the case of the Walloon Parliament and the federal House of Representatives, and 36\% in the case of the Parliament of the German Community. ${ }^{1}$ Only the latter does worse than the local level. This data hides differences among municipalities but nonetheless seems to reflect a rather closed local political level unwilling to address gender equality at the same rhythm as other electoral levels do (Celis, Erzeel \& Meier, 2013; Meier, 2007, 2008; Meier \& Verlet, 2008a, 2008b, 2011). This is all the more interesting as the local political level is often presented as being most apt to experiment with new forms of democratic organisation and democratic renewal (Caluwaerts, Reuchamps \& Brans, 2013).

This puzzle is taken as a starting point to explore gender (in)equality in local politics in Belgium (and, more precisely, Flanders) from the perspective of local party branches, using data from the 2018 RepResent Local Chairs Survey, in combination with two earlier editions of this Survey (2006, 2012) (Buelens, Rihoux \& Deschouwer, 2008; Deschouwer, Verthé \& Rihoux, 2013). Local party branches are crucial players in the political arena. They act as gatekeepers in the recruitment and selection of candidates for local office, offer a direct linkage to citizens, bridge the local and higher political levels and serve as training grounds for party members with political ambition (Clark, 2004). Given their relevance, in combination with the lagging behind of the local electoral level, it is important to scrutinise local party branches.

We do so by investigating the 'feminisation' of local party branches, a concept developed by Childs and Webb (2011). Feminisation refers to the integration of women in political parties, either as party members, executives or party leaders (which we label 'internal' feminisation) or as candidates and elected representatives in electoral politics (which we label 'external' feminisation). In this article, we are interested in the question of how both forms of feminisation are connected and how, in particular, the 'internal' feminisation of local party branches might help us to better understand the 'external' feminisation of local electoral politics. More precisely, we examine: i) to what extent local party branches are (internally) feminised and whether and how this is linked to ii) the recruitment problems they encounter for political candidates and iii) their support for, and adoption of, measures to promote gender equality among these candidates. Three clarifications are in place at this point. First, our measurement of 'external' feminisation focuses more on parties' experiences, perceptions and structural measures of feminisation than on the actual numbers of elected men and women, ${ }^{2}$ which was in line with the ambitions of the Local Chairs Survey. 
Second, although we study the link between internal and external feminisation, and assume that this link is causal, we refrain from drawing too firm conclusions on the unidirectional nature of this causal link. In reality, it is likely that processes of internal and external feminisation mutually affect each other; yet this is something that we could not test with the available data and therefore falls outside the scope of this article. Finally, and linked to the foregoing, it goes without saying that many factors influence the actual numerical presence of women in local politics and might impact the lagging behind of the local level as compared with the others, among which the internal feminisation of local party branches is but one. Nonetheless, as in Belgium, the same proportional list system and gender quotas apply to all electoral levels, these institutional factors can herewith be put aside.

In the next two sections, we address the state of the art on the role of gender in local (party) politics and provide an overview of the representation of women in Belgian local politics. The third section discusses the methods and data on which our further investigation is based. In the three following sections, we present our findings. The fourth section describes the internal feminisation of local parties. The fifth section examines problems local party branches encounter in the recruitment of candidates for elections. The sixth section analyses the (attitudes towards the) measures taken to further promote the external feminisation of local politics. The conclusion sums up the main findings and defines roads for future research.

\section{Gender in Local Politics: A State of the Art}

When we turn to the literature on gender in local politics, an overall observation is that research on the topic is scarce (Pini \& McDonald, 2011). While the overall literature on the position of women in politics has burgeoned over the last two decades (for a good overview, see Childs \& Lovenduski, 2013), we find less on the local level. Moreover, the existing literature on the gender gap in local politics predominantly focuses on female mayors, covering mainly Australia or the USA (Pini, 2007; Smith, Reingold \& Owens, 2012). These studies show that a variety of factors, ranging from the macro to the micro level, shape women's position in local politics. There is, however, comparatively less work on Europe, and if there is, it covers the impact of macro-level factors rather than providing a clear picture on the ground (although there are exceptions, see Hedlund, 1988). In what follows, we first offer an overview of existing research on gender in local politics, before delving deeper into the main focus of this article, namely the role of parties in women's political representation.

The existing literature on gender and local politics touches on gendered inroads to elected office and local politics as a masculine political biotope. Together, these studies show that macro-level factors linked to the institutional, political and socio-economic context as well as micro-level factors linked to supply- and demand-side considerations shape the overall conditions for women's presence in local politics. 
European studies on the topic centre mostly on the macro level, focussing, first of all, on how electoral rules and the adoption of gender quotas influence women's electoral chances. Together, these studies show that, similar to what is found at the national level, more open electoral systems such as proportional list systems, and high district and party magnitude, are more favourable for achieving a gender balance. Similarly, gender quotas, when they are effectively designed with placement mandates and strict sanctions and well adapted to the electoral system, impact positively on the number of women elected (Holli, 2011; Magin, 2011; Meier \& Verlet, 2008b; Ransford \& Thomson, 2011; Sundström \& Stockemer, 2015). Equally important is the socio-economic and socio-demographic situation in the municipality, including the level of female labour force participation, the size of the municipality and the degree of urbanisation (Smith et al., 2012; Sundström \& Stockemer, 2015). Smith et al. (2012), studying American cities, for instance, found that a larger size of city and a more liberal background is helpful in getting women elected. In a similar vein, Pini (2007) found that female mayors in Australian rural areas face rather hegemonic masculine political arenas, making it difficult for them to get elected and - once elected - to establish their position as mayor.

At the micro level, dynamics of supply and demand play a role (Norris \& Lovenduski, 1993a, 1993b). The supply of female candidates and their decision (not) to run for office is shaped by a variety of factors, including constraints on resources (e.g. money, time); self-perceived qualifications/experience and viability; (negative) perceptions of electoral politics; gender differences in political ambition; and gendered dynamics of candidate emergence (Josefsson, 2020; Lawless \& Fox, 2010; Norris \& Lovenduski, 1993a, 1993b; Piscopo \& Kenny, 2020). Studying mayors in a broad range of countries across Europe, Johansson (2006) found that a crucial source for female mayors, more than for their male colleagues, was their embedment within a 'political community'. Female mayors were more often than their male colleagues socialised in a political family and more often occupied a position in their party (Johansson, 2006). Carroll and Sanbonmatsu (2010), focussing on American mayors, confirm this finding and show that female mayors had more political experience than male mayors when they ran for municipal office (Carroll \& Sanbonmatsu, 2010). The family context also plays a role as a source of encouragement/discouragement for future female mayors. In their studies, Briggs (2000) and Carroll and Sanbonmatsu (2010) found that support by the partner is considered important by both male and female mayors in Canada, the UK and USA, but that women faced more discouragement from partners and family than men did. Recent research in Flanders (Emery, Meier \& Mortelmans, 2018) and Sweden (Johansson Sevä \& Öun, 2019) shows that local women politicians face higher levels of work-family conflict and spend more energy and time on coordinating family life than their male colleagues, although this also depends on the way the welfare state regulates dependence on spouses and family for income and care facilities (Johansson, 2006).

Demand-side factors, and, in particular, the gatekeeping role played by political parties, have so far received the least attention in studies on gender and local politics. This absence can be partly explained by the predominant focus on may- 
ors in previous research but also by the small role parties play in some contexts. However, in 'partitocracies' like Belgium, parties are as crucial for understanding the gendered dynamics of candidate nomination in both local and national settings (Leyenaar, 2004; Mügge, Runderkamp \& Kranendonk, 2019; Norris \& Lovenduski, 1993b). From previous research based on national elections, it follows that a variety of party-related factors, including party ideology, party organisational rules and gendered practices, affect women's presence on candidate lists, albeit in different degrees (Kittilson, 2006; Norris \& Lovenduski, 1993a). Regarding party ideology, a common finding is that left-wing parties are more likely than right-wing parties to recruit female candidates and to support women-friendly policies, although there is evidence that this holds particularly for 'new left' parties (Kittilson, 2006) and that (at least some) rightist parties might be 'catching up' (Erzeel \& Celis,2016; Norris \& Lovenduski, 1993a). The composition of selectorates also plays a role. Some studies show that party elites prefer candidates like themselves, which Niven (1998) has called the 'in-group effect'. When selectorates disproportionally consist of men, this disadvantages women as they are more likely to be treated as 'outgroups' and as less likeable and reliable candidates. This 'outgroup effect' can be countered by having more 'active women' in the party, as Kittilson (2006) has argued, or by adopting specific measures such as internal party quotas to redress structural gender inequalities within parties. However, even in these latter cases, informal gendered recruitment practices and gender-biased notions of what makes a 'competent' candidate still risk hindering women's access to power (Bjarnegård, 2013; Murray, 2015). In that sense, more research is needed on the considerations of party elites when it comes to the nomination of candidates at the local level. This article is aimed at making such a contribution.

In our empirical analyses, we therefore focus on the 'feminisation' of local party branches. The terminology of 'feminisation' ties back to Childs and Webb's (2011) work and captures the extent to which political parties promote the integration of women in the party. In that sense, we study what they label 'descriptive' feminisation, leaving aside the 'substantive' dimension of feminisation (i.e. the integration of women's concerns at the party level). Childs and Webb (2011), furthermore, distinguish between feminist and feminised political parties. While both types of parties promote the integration of women, feminist parties also put forward a gender equality-promoting perspective regarding its own organisation as well as the societal project it strives for. In our study, we include both types of parties. Moreover, we make a distinction between what we label 'internal' and 'external' feminisation. The former relates to the integration of women in local party branches, as party leaders, executive members or rank-and-file members. The latter refers to the integration of women as candidates and, in particular, the existence of rules and practices supporting the integration of female candidates in local electoral politics. Our main goal is to first map patterns of internal party feminisation and then examine whether they are in some way linked to parties' external feminisation. We thus hope to further our understanding of how demand-side factors shape the political representation of women in local politics and the role played by 'active women' in the party (see Kittilson, 2006). However, 
while the focus in this manuscript is on the demand side, we concur with recent studies that supply and demand dynamics are in many ways interconnected (Josefsson, 2020; Piscopo \& Kenny, 2020). In a recent article, Josefsson (2020: 61), for instance, shows that candidate selection procedures shape and 'gender' the meaning of political ambition. Investigating the initiatives deployed by local parties, as we do in this article, therefore, sheds light not only on the demand side, but also on the supply side, as it provides for a clearer understanding of how local party branches perceive the supply side of the political process, how they eventually perceive men and women candidates differently and how this may foster gendered recruitment and selection practices.

\section{The Representation of Women in Belgian Local Politics}

Compared with other European countries, the promotion of women's representation came rather late in Belgium, despite its proportional representation (PR)-list electoral system (Meier, 2012). The feminisation of formal politics in the Netherlands, for instance, took off more than a decade earlier than in Belgium (Oldersma, 2002). However, despite its slower start, there is a general tendency towards a stronger institutionalisation of gender in political life, particularly through the use of legally binding gender quotas. Belgium was the first country in the world to impose strict gender quotas by law for all electoral levels. The first gender quota acts for electoral lists (the 'Smet-Tobback' law), adopted in 1994, specified that all candidate lists must not present more than two-thirds of candidates of either sex. The second gender quota acts, adopted in 2002 and still applicable today in Flanders, stipulated that candidate lists should consist of an equal number of men and women and that the top two positions on each list must be occupied by candidates of different sexes. Furthermore, both in Brussels and Wallonia (the organisation of local elections falls under the remit of the regions), a zipper principle applies to the entire list of candidates, which means that male and female candidates fully alternate on the list of effective candidates and substitutes. With this zipper principle, the Brussels and Walloon quotas belong to the most far-reaching gender quotas worldwide.

As the gender quota stipulations have increasingly become more stringent since the 1990s, the numbers of women in local politics have also increased over the years, as shown in Table 1 . Whereas in 1988, the last local elections before the introduction of gender quotas, barely $14 \%$ of women were elected, this figure rose to $39 \%$ in the latest local elections of 2018 . However, while the gender quotas did play a role in facilitating women's access to elected office because of efficient sanctions (i.e. parties not complying with the quotas are not allowed to participate in elections), the increase in women's presence cannot solely or entirely be attributed to the direct effects of the quota laws. The effects of these rules still depend on district/party magnitude. A high percentage of women on the lists of candidates bear fruit in larger circumscriptions, and the zipper principle at the top of each list has the most impact in small circumscriptions (Meier, 2012; Sliwa, Meier \& Thijssen, 2011). 
Table 1 Women candidates/elected/councillors/aldermen/mayors in local elections 1988-2018

\begin{tabular}{|c|c|c|c|c|}
\hline \multirow{3}{*}{ Table 1} & \multicolumn{4}{|c|}{ The Feminisation of Belgian Local Party Politics } \\
\hline & \multicolumn{4}{|c|}{$\begin{array}{l}\text { Women candidates/elected/councillors/aldermen/mayors in local } \\
\text { elections 1988-2018 }\end{array}$} \\
\hline & Brussels & Flanders & Wallonia & Total Belgium \\
\hline \multicolumn{5}{|c|}{ I 988 no gender quotas imposed by law } \\
\hline \multicolumn{5}{|c|}{ Candidates } \\
\hline Elected & $26 \%$ & $14 \%$ & $12 \%$ & $14 \%$ \\
\hline Councillors & & & & $14 \%$ \\
\hline Aldermen & & & & $10 \%$ \\
\hline Mayors & & & & $4 \%$ \\
\hline \multicolumn{5}{|c|}{ I 994 temporary gender quotas of at least $25 \%$ candidates of the under-represented sex } \\
\hline Candidates & $40 \%$ & $32 \%$ & $31 \%$ & $32 \%$ \\
\hline Elected & $28 \%$ & $20 \%$ & $18 \%$ & $20 \%$ \\
\hline Councillors & & & & $20 \%$ \\
\hline Aldermen & $23 \%$ & $15 \%$ & $10 \%$ & $13 \%$ \\
\hline Mayors & $11 \%$ & $5 \%$ & $5 \%$ & $5 \%$ \\
\hline \multicolumn{5}{|c|}{2000 gender quotas of at least $33 \%$ candidates of the under-represented sex } \\
\hline Candidates & $44 \%$ & $39 \%$ & $40 \%$ & $40 \%$ \\
\hline Elected & $38 \%$ & $27 \%$ & $26 \%$ & $27 \%$ \\
\hline Councillors & $37 \%$ & $27 \%$ & $26 \%$ & $31 \%$ \\
\hline Aldermen & $31 \%$ & $20 \%$ & $18 \%$ & $20 \%$ \\
\hline Mayors & $16 \%$ & $8 \%$ & $8 \%$ & $8 \%$ \\
\hline \multicolumn{5}{|c|}{$\begin{array}{l}\text { 2006* gender quotas of } 50 \% \text { of candidates of each sex and zipper principle for first two (Brus- } \\
\text { sels and Wallonia) or three (Flanders) list positions }\end{array}$} \\
\hline Elected & $42 \%$ & $33 \%$ & $32 \%$ & $33 \%$ \\
\hline Councillors & $40 \%$ & $34 \%$ & $24 \%$ & $33 \%$ \\
\hline Aldermen & $38 \%$ & $31 \%$ & $28 \%$ & $31 \%$ \\
\hline Mayors & $16 \%$ & $9 \%$ & $9 \%$ & $10 \%$ \\
\hline \multicolumn{5}{|c|}{$\begin{array}{l}2012 * \text { gender quotas of } 50 \% \text { of candidates of each sex and zipper principle for first two list } \\
\text { positions }\end{array}$} \\
\hline Elected & $41 \%$ & $36 \%$ & $35 \%$ & $36 \%$ \\
\hline Councillors & $43 \%$ & $36 \%$ & $36 \%$ & $36 \%$ \\
\hline Aldermen & $40 \%$ & $33 \%$ & $30 \%$ & $32 \%$ \\
\hline Mayors & $5 \%$ & $13 \%$ & $13 \%$ & $12 \%$ \\
\hline \multicolumn{5}{|c|}{$\begin{array}{l}2018 * \text { gender quotas of } 50 \% \text { of candidates of each sex and zipper principle for entire list } \\
\text { (Brussels and Wallonia) or first two (Flanders) list positions }\end{array}$} \\
\hline Elected & $49 \%$ & $38 \%$ & $39 \%$ & $39 \%$ \\
\hline
\end{tabular}

1994 temporary gender quotas of at least $25 \%$ candidates of the under-represented sex

\begin{tabular}{|c|c|c|c|c|}
\hline \multirow{3}{*}{ Table 1} & \multicolumn{4}{|c|}{ The Feminisation of Belgian Local Party Politics } \\
\hline & \multicolumn{4}{|c|}{$\begin{array}{l}\text { Women candidates/elected/councillors/aldermen/mayors in local } \\
\text { elections 1988-2018 }\end{array}$} \\
\hline & Brussels & Flanders & Wallonia & Total Belgium \\
\hline \multicolumn{5}{|c|}{1988 no gender quotas imposed by law } \\
\hline \multicolumn{5}{|c|}{ Candidates } \\
\hline Elected & $26 \%$ & $14 \%$ & $12 \%$ & $14 \%$ \\
\hline Councillors & & & & $14 \%$ \\
\hline Aldermen & & & & $10 \%$ \\
\hline Mayors & & & & $4 \%$ \\
\hline \multicolumn{5}{|c|}{1994 temporary gender quotas of at least $25 \%$ candidates of the under-represented sex } \\
\hline Candidates & $40 \%$ & $32 \%$ & $31 \%$ & $32 \%$ \\
\hline Elected & $28 \%$ & $20 \%$ & $18 \%$ & $20 \%$ \\
\hline Councillors & & & & $20 \%$ \\
\hline Aldermen & $23 \%$ & $15 \%$ & $10 \%$ & $13 \%$ \\
\hline Mayors & $11 \%$ & $5 \%$ & $5 \%$ & $5 \%$ \\
\hline \multicolumn{5}{|c|}{2000 gender quotas of at least $33 \%$ candidates of the under-represented sex } \\
\hline Candidates & $44 \%$ & $39 \%$ & $40 \%$ & $40 \%$ \\
\hline Elected & $38 \%$ & $27 \%$ & $26 \%$ & $27 \%$ \\
\hline Councillors & $37 \%$ & $27 \%$ & $26 \%$ & $31 \%$ \\
\hline Aldermen & $31 \%$ & $20 \%$ & $18 \%$ & $20 \%$ \\
\hline Mayors & $16 \%$ & $8 \%$ & $8 \%$ & $8 \%$ \\
\hline \multicolumn{5}{|c|}{$\begin{array}{l}\text { 2006* gender quotas of } 50 \% \text { of candidates of each sex and zipper principle for first two (Brus- } \\
\text { sels and Wallonia) or three (Flanders) list positions }\end{array}$} \\
\hline Elected & $42 \%$ & $33 \%$ & $32 \%$ & $33 \%$ \\
\hline Councillors & $40 \%$ & $34 \%$ & $24 \%$ & $33 \%$ \\
\hline Aldermen & $38 \%$ & $31 \%$ & $28 \%$ & $31 \%$ \\
\hline Mayors & $16 \%$ & $9 \%$ & $9 \%$ & $10 \%$ \\
\hline \multicolumn{5}{|c|}{$\begin{array}{l}2012 * \text { gender quotas of } 50 \% \text { of candidates of each sex and zipper principle for first two list } \\
\text { positions }\end{array}$} \\
\hline Elected & $41 \%$ & $36 \%$ & $35 \%$ & $36 \%$ \\
\hline Councillors & $43 \%$ & $36 \%$ & $36 \%$ & $36 \%$ \\
\hline Aldermen & $40 \%$ & $33 \%$ & $30 \%$ & $32 \%$ \\
\hline Mayors & $5 \%$ & $13 \%$ & $13 \%$ & $12 \%$ \\
\hline \multicolumn{5}{|c|}{$\begin{array}{l}2018 \text { * gender quotas of } 50 \% \text { of candidates of each sex and zipper principle for entire list } \\
\text { (Brussels and Wallonia) or first two (Flanders) list positions }\end{array}$} \\
\hline Elected & $49 \%$ & $38 \%$ & $39 \%$ & $39 \%$ \\
\hline
\end{tabular}

2000 gender quotas of at least $33 \%$ candidates of the under-represented sex

\begin{tabular}{|c|c|c|c|c|}
\hline \multirow{3}{*}{ Table 1} & \multicolumn{4}{|c|}{ The Feminisation of Belgian Local Party Politics } \\
\hline & \multicolumn{4}{|c|}{$\begin{array}{l}\text { Women candidates/elected/councillors/aldermen/mayors in local } \\
\text { elections 1988-2018 }\end{array}$} \\
\hline & Brussels & Flanders & Wallonia & Total Belgium \\
\hline \multicolumn{5}{|c|}{1988 no gender quotas imposed by law } \\
\hline \multicolumn{5}{|c|}{ Candidates } \\
\hline Elected & $26 \%$ & $14 \%$ & $12 \%$ & $14 \%$ \\
\hline Councillors & & & & $14 \%$ \\
\hline Aldermen & & & & $10 \%$ \\
\hline Mayors & & & & $4 \%$ \\
\hline \multicolumn{5}{|c|}{1994 temporary gender quotas of at least $25 \%$ candidates of the under-represented sex } \\
\hline Candidates & $40 \%$ & $32 \%$ & $31 \%$ & $32 \%$ \\
\hline Elected & $28 \%$ & $20 \%$ & $18 \%$ & $20 \%$ \\
\hline Councillors & & & & $20 \%$ \\
\hline Aldermen & $23 \%$ & $15 \%$ & $10 \%$ & $13 \%$ \\
\hline Mayors & $11 \%$ & $5 \%$ & $5 \%$ & $5 \%$ \\
\hline \multicolumn{5}{|c|}{2000 gender quotas of at least $33 \%$ candidates of the under-represented sex } \\
\hline Candidates & $44 \%$ & $39 \%$ & $40 \%$ & $40 \%$ \\
\hline Elected & $38 \%$ & $27 \%$ & $26 \%$ & $27 \%$ \\
\hline Councillors & $37 \%$ & $27 \%$ & $26 \%$ & $31 \%$ \\
\hline Aldermen & $31 \%$ & $20 \%$ & $18 \%$ & $20 \%$ \\
\hline Mayors & $16 \%$ & $8 \%$ & $8 \%$ & $8 \%$ \\
\hline \multicolumn{5}{|c|}{$\begin{array}{l}\text { 2006* gender quotas of } 50 \% \text { of candidates of each sex and zipper principle for first two (Brus- } \\
\text { sels and Wallonia) or three (Flanders) list positions }\end{array}$} \\
\hline Elected & $42 \%$ & $33 \%$ & $32 \%$ & $33 \%$ \\
\hline Councillors & $40 \%$ & $34 \%$ & $24 \%$ & $33 \%$ \\
\hline Aldermen & $38 \%$ & $31 \%$ & $28 \%$ & $31 \%$ \\
\hline Mayors & $16 \%$ & $9 \%$ & $9 \%$ & $10 \%$ \\
\hline \multicolumn{5}{|c|}{$\begin{array}{l}2012 * \text { gender quotas of } 50 \% \text { of candidates of each sex and zipper principle for first two list } \\
\text { positions }\end{array}$} \\
\hline Elected & $41 \%$ & $36 \%$ & $35 \%$ & $36 \%$ \\
\hline Councillors & $43 \%$ & $36 \%$ & $36 \%$ & $36 \%$ \\
\hline Aldermen & $40 \%$ & $33 \%$ & $30 \%$ & $32 \%$ \\
\hline Mayors & $5 \%$ & $13 \%$ & $13 \%$ & $12 \%$ \\
\hline \multicolumn{5}{|c|}{$\begin{array}{l}2018 \text { * gender quotas of } 50 \% \text { of candidates of each sex and zipper principle for entire list } \\
\text { (Brussels and Wallonia) or first two (Flanders) list positions }\end{array}$} \\
\hline Elected & $49 \%$ & $38 \%$ & $39 \%$ & $39 \%$ \\
\hline
\end{tabular}

2006* gender quotas of $50 \%$ of candidates of each sex and zipper principle for first two (Brussels and Wallonia) or three (Flanders) list positions

\begin{tabular}{|c|c|c|c|c|}
\hline \multirow{3}{*}{ Table 1} & \multicolumn{4}{|c|}{ The Feminisation of Belgian Local Party Politics } \\
\hline & \multicolumn{4}{|c|}{$\begin{array}{l}\text { Women candidates/elected/councillors/aldermen/mayors in local } \\
\text { elections 1988-2018 }\end{array}$} \\
\hline & Brussels & Flanders & Wallonia & Total Belgium \\
\hline \multicolumn{5}{|c|}{ I 988 no gender quotas imposed by law } \\
\hline \multicolumn{5}{|c|}{ Candidates } \\
\hline Elected & $26 \%$ & $14 \%$ & $12 \%$ & $14 \%$ \\
\hline Councillors & & & & $14 \%$ \\
\hline Aldermen & & & & $10 \%$ \\
\hline Mayors & & & & $4 \%$ \\
\hline \multicolumn{5}{|c|}{ I 994 temporary gender quotas of at least $25 \%$ candidates of the under-represented sex } \\
\hline Candidates & $40 \%$ & $32 \%$ & $31 \%$ & $32 \%$ \\
\hline Elected & $28 \%$ & $20 \%$ & $18 \%$ & $20 \%$ \\
\hline Councillors & & & & $20 \%$ \\
\hline Aldermen & $23 \%$ & $15 \%$ & $10 \%$ & $13 \%$ \\
\hline Mayors & $11 \%$ & $5 \%$ & $5 \%$ & $5 \%$ \\
\hline \multicolumn{5}{|c|}{2000 gender quotas of at least $33 \%$ candidates of the under-represented sex } \\
\hline Candidates & $44 \%$ & $39 \%$ & $40 \%$ & $40 \%$ \\
\hline Elected & $38 \%$ & $27 \%$ & $26 \%$ & $27 \%$ \\
\hline Councillors & $37 \%$ & $27 \%$ & $26 \%$ & $31 \%$ \\
\hline Aldermen & $31 \%$ & $20 \%$ & $18 \%$ & $20 \%$ \\
\hline Mayors & $16 \%$ & $8 \%$ & $8 \%$ & $8 \%$ \\
\hline \multicolumn{5}{|c|}{$\begin{array}{l}\text { 2006* gender quotas of } 50 \% \text { of candidates of each sex and zipper principle for first two (Brus- } \\
\text { sels and Wallonia) or three (Flanders) list positions }\end{array}$} \\
\hline Elected & $42 \%$ & $33 \%$ & $32 \%$ & $33 \%$ \\
\hline Councillors & $40 \%$ & $34 \%$ & $24 \%$ & $33 \%$ \\
\hline Aldermen & $38 \%$ & $31 \%$ & $28 \%$ & $31 \%$ \\
\hline Mayors & $16 \%$ & $9 \%$ & $9 \%$ & $10 \%$ \\
\hline \multicolumn{5}{|c|}{$\begin{array}{l}2012 * \text { gender quotas of } 50 \% \text { of candidates of each sex and zipper principle for first two list } \\
\text { positions }\end{array}$} \\
\hline Elected & $41 \%$ & $36 \%$ & $35 \%$ & $36 \%$ \\
\hline Councillors & $43 \%$ & $36 \%$ & $36 \%$ & $36 \%$ \\
\hline Aldermen & $40 \%$ & $33 \%$ & $30 \%$ & $32 \%$ \\
\hline Mayors & $5 \%$ & $13 \%$ & $13 \%$ & $12 \%$ \\
\hline \multicolumn{5}{|c|}{$\begin{array}{l}2018 * \text { gender quotas of } 50 \% \text { of candidates of each sex and zipper principle for entire list } \\
\text { (Brussels and Wallonia) or first two (Flanders) list positions }\end{array}$} \\
\hline Elected & $49 \%$ & $38 \%$ & $39 \%$ & $39 \%$ \\
\hline
\end{tabular}

20 I 2* gender quotas of $50 \%$ of candidates of each sex and zipper principle for first two list positions

\begin{tabular}{|c|c|c|c|c|}
\hline \multirow{3}{*}{ Table 1} & \multicolumn{4}{|c|}{ The Feminisation of Belgian Local Party Politics } \\
\hline & \multicolumn{4}{|c|}{$\begin{array}{l}\text { Women candidates/elected/councillors/aldermen/mayors in local } \\
\text { elections 1988-2018 }\end{array}$} \\
\hline & Brussels & Flanders & Wallonia & Total Belgium \\
\hline \multicolumn{5}{|c|}{ I 988 no gender quotas imposed by law } \\
\hline \multicolumn{5}{|c|}{ Candidates } \\
\hline Elected & $26 \%$ & $14 \%$ & $12 \%$ & $14 \%$ \\
\hline Councillors & & & & $14 \%$ \\
\hline Aldermen & & & & $10 \%$ \\
\hline Mayors & & & & $4 \%$ \\
\hline \multicolumn{5}{|c|}{1994 temporary gender quotas of at least $25 \%$ candidates of the under-represented sex } \\
\hline Candidates & $40 \%$ & $32 \%$ & $31 \%$ & $32 \%$ \\
\hline Elected & $28 \%$ & $20 \%$ & $18 \%$ & $20 \%$ \\
\hline Councillors & & & & $20 \%$ \\
\hline Aldermen & $23 \%$ & $15 \%$ & $10 \%$ & $13 \%$ \\
\hline Mayors & $11 \%$ & $5 \%$ & $5 \%$ & $5 \%$ \\
\hline \multicolumn{5}{|c|}{2000 gender quotas of at least $33 \%$ candidates of the under-represented sex } \\
\hline Candidates & $44 \%$ & $39 \%$ & $40 \%$ & $40 \%$ \\
\hline Elected & $38 \%$ & $27 \%$ & $26 \%$ & $27 \%$ \\
\hline Councillors & $37 \%$ & $27 \%$ & $26 \%$ & $31 \%$ \\
\hline Aldermen & $31 \%$ & $20 \%$ & $18 \%$ & $20 \%$ \\
\hline Mayors & $16 \%$ & $8 \%$ & $8 \%$ & $8 \%$ \\
\hline \multicolumn{5}{|c|}{$\begin{array}{l}\text { 2006* gender quotas of } 50 \% \text { of candidates of each sex and zipper principle for first two (Brus- } \\
\text { sels and Wallonia) or three (Flanders) list positions }\end{array}$} \\
\hline Elected & $42 \%$ & $33 \%$ & $32 \%$ & $33 \%$ \\
\hline Councillors & $40 \%$ & $34 \%$ & $24 \%$ & $33 \%$ \\
\hline Aldermen & $38 \%$ & $31 \%$ & $28 \%$ & $31 \%$ \\
\hline Mayors & $16 \%$ & $9 \%$ & $9 \%$ & $10 \%$ \\
\hline \multicolumn{5}{|c|}{$\begin{array}{l}2012 * \text { gender quotas of } 50 \% \text { of candidates of each sex and zipper principle for first two list } \\
\text { positions }\end{array}$} \\
\hline Elected & $41 \%$ & $36 \%$ & $35 \%$ & $36 \%$ \\
\hline Councillors & $43 \%$ & $36 \%$ & $36 \%$ & $36 \%$ \\
\hline Aldermen & $40 \%$ & $33 \%$ & $30 \%$ & $32 \%$ \\
\hline Mayors & $5 \%$ & $13 \%$ & $13 \%$ & $12 \%$ \\
\hline \multicolumn{5}{|c|}{$\begin{array}{l}2018 * \text { gender quotas of } 50 \% \text { of candidates of each sex and zipper principle for entire list } \\
\text { (Brussels and Wallonia) or first two (Flanders) list positions }\end{array}$} \\
\hline Elected & $49 \%$ & $38 \%$ & $39 \%$ & $39 \%$ \\
\hline
\end{tabular}

$2018 *$ gender quotas of $50 \%$ of candidates of each sex and zipper principle for entire list (Brussels and Wallonia) or first two (Flanders) list positions

Councillors $\quad 47 \% \quad 38 \%$

Aldermen $\quad 41 \% \quad 38 \%$

$\begin{array}{lllll}\text { Mayors } & 5 \% & 14 \% & 18 \% * * & 15 \% * *\end{array}$

empty cells $=$ data not available; $*$ candidates not mentioned as per definition $50 \%$; **own data. Source: Meier 2007; https://igvm-iefh.belgium.be/nl/activiteiten/politiek/cijfers (at 28 November 2019). 
Similarly to the numbers of women elected, the numbers of women aldermen and mayors have increased over the years, though at a slower pace (see Table 1). Back in $1988,10 \%$ of the aldermen and $4 \%$ of the mayors were women. In the aftermath of the latest local elections of $2018,41 \%$ and $38 \%$ of the aldermen are women in, respectively, Brussels and Flanders (the Walloon authorities were not able to provide for that data). However, women still do not make up more than $15 \%$ of the mayors across Belgium. In sum, Belgian local electoral politics underwent a feminisation over time, lagging behind the evolution taking place at the other electoral levels, but nonetheless following a similar pattern: initial increases stagnate once high numbers of women are reached; but the higher one climbs the political ladder, the lower the number of women, which is especially clear when we look at the position of mayors.

\section{Methods and Data}

The data presented in the previous section reveal some patterns in the 'external' feminisation of Flemish local parties. In the rest of the article, we will dig deeper and shed light on (the interplay between) internal and external feminisation. We do so in the following sections by sketching patterns in the level of 'internal' feminisation of the Flemish local parties (Section 4) and by investigating whether this goes hand in hand with gendered recruitment problems (Section 5) and structural measures to promote women in politics (Section 6). To address these questions, we primarily draw on data from the RepResent Local Chairs Survey 2018, but also include data from two previous Local Chairs Surveys (2006, 2012) (Buelens, Rihoux \& Deschouwer, 2008; Deschouwer, Verthé \& Rihoux, 2013) to present an evolution over time in Section 4. The Local Chair Survey is conducted every six years among the chairpersons of the municipal branches of Belgian national parties during the local elections. Included in the survey are all municipal branches of the national parties irrespective of the name they used on the ballot, thereby excluding only genuinely local parties that ran in one municipality only. For the most recent survey in 2018, the local branches' chairs were invited to participate in an online survey in Summer 2018, a few months before the 14 October local elections. The contact addresses were obtained from the national parties' central offices. Among others, chairpersons were asked about the (local) party's organisation, activities, recruitment and selection strategies and for their opinion on a number of issues. We refer to the Introduction of this Special Issue (Wauters, Otjes \& van Haute, 2020) for more detailed information on the survey methodology.

For this article, the analysis is restricted to the answers of the respondents chairing a Flemish local party, active in either Flanders $(\mathrm{N}=405)$ or the Brussels Capital Region $(\mathrm{N}=19)$. The major party families are included: the green party, Groen $(N=74)$, the social democratic party, Sp.a $(N=93)$, the Christian democratic party, $C D \& V(N=108)$, the liberal party, Open VLD $(N=31)$, the regionalist/conservative party, $\mathrm{N}-\mathrm{VA}(\mathrm{N}=86)$, and the radical right party, Vlaams Belang $(\mathrm{N}=34)$. These parties represent the major party families in Flanders and reflect 
different ideological streams: Groen and Sp.a are (centre-)left parties, CD\&V is a centre party, Open VLD and N-VA are (centre-)right parties and Vlaams Belang is radical right. Given the low response rate among some of the French-speaking parties (most notably the green party Ecolo and socialist party PS), they were not included in the analysis. Furthermore, we also decided to exclude the answers from the local chairs of PVDA, the Flemish radical left party, as the sample size is not large enough to draw any conclusions.

The first part of the analysis in Section 4 sketches the evolution in the degree of feminisation in the parties' leadership, executive committees and membership bases. For these analyses, we use data from the Local Chairs Surveys of 2006, 2012 and 2018. First, data on the gender of the party chairs was mostly directly derived from the Local Chairs Survey, as most of the surveys were answered by the local party chairs, and respondents were asked to indicate their gender. However, in some cases the survey was filled out by another person (e.g. a member of the executive committee, the head of list candidate, and so forth). For these cases, we collected information on the gender of the local party chair ourselves from local party websites and social media accounts. The latter was possible only for 2018, as this information could not be traced back for 2006 and 2012. Our analyses for these two years are therefore limited to the answers of those respondents who indicated that they chaired the party themselves. Second, and in relation to the executive committees and party membership base, local chairs were asked to indicate how many of the total number of executive committee members and the total number of party members of their respective local branches were women. It is worth noting that across the surveys, not all respondents managed to recall the number of (female) members equally well. This resulted in a low response rate for the survey question on female party members (37\%) compared with the question on female executive members (89\%). Moreover, since we could assume that party chairs who know and monitor the numbers of female members also pay more attention to gender issues (and arguably, to achieving a gender balance in the local branch), this might be seen as a shortcoming of the study and also means that the findings regarding party members should be interpreted with caution.

The fact that different questions were part of several versions of the Local Chairs Survey enabled us to present an (albeit, limited) evolution over time. We take 2006 as the starting point for this analysis, since more stringent quota regulations were for the first time applied during the 2006 local elections. Data can only be considered at the aggregated level, given that we do not know whether the same respondents completed the questionnaires over the years.

In Sections 5 and 6 of the analysis, the interplay between internal and external party feminisation is studied. Owing to a lack of data, these sections do not involve a comparison over time but only rely on the answers collected in 2018. Section 5 focuses on problems regarding the recruitment of candidates. Local chairpersons were asked to indicate whether they face one or more of four problems related to the recruitment of candidates and to specify whether this holds for male candidates and/or female candidates ${ }^{3}$ : 'There is lack of interest in a political career', 'Politics has a bad name', 'Few people recognise themselves in the 
party' and 'Few candidates present themselves spontaneously'. Respondents could tick multiple boxes if multiple problems presented themselves.

Section 6 explores the attitudes of local party chairs towards gender quotas and the extent to which parties have adopted other, more far-reaching, measures to promote a gender balance on local lists. In order to do so, we look at party chairs' responses to two questions asking whether they think the government or the national party leadership can impose binding quota regulations for women ('yes' or 'no') 4 . We also analyse the chairpersons' responses to questions asking whether agreements exist at the level of the local branch about the extension of the zipper principle on the entire candidate list ('yes' or 'no') and the appointment of female head of list candidates ('yes' or 'no'). ${ }^{5}$

The analyses in Sections 5 and 6 are first presented at the party level. This allows us to examine whether differences can be observed between the various parties and party families. In a next step, we present analyses for different subgroups on a number of variables linked to parties' level of internal feminisation. First, a distinction is made on the basis of the gender of local party chair to test any in-/outgroup effect (Niven, 1998). Second, we compare results for different levels of female presence among the party memberships and executive committees. Our cut-off point for the percentage of female party executives is $30 \%$, in line with the critical mass argument (Dahlerup, 1988), which assumes that if the percentage of women within an organisation exceeds a particular threshold (often 30\%), this might have positive effects on the woman-friendliness of existing practices. Given that the same argument does not apply to the membership base, we use a different cut-off point of $40 \%$. This cut-off point is stricter because the threshold for becoming a member is lower and because the cut-off point is closer to the variable median of $42 \%$.

\section{The Internal Feminisation of Local Party Branches}

We now turn to the results for the internal feminisation of (Flemish) local party branches and consider the integration of women as party members, executive committee members and party leaders.

With regard to the number of female party members, we see that, on a general level, women make up on average $42 \%$ of the membership in $2006,40 \%$ in 2012 and $41 \%$ in 2018. Hence, they remain under-represented, and the numbers are stagnating, although low response rates for this question potentially affect the overall results. Right-wing parties (N-VA and especially Vlaams Belang) are less successful in attracting female members than other parties, which may come as no surprise since leftist parties are generally considered to express a greater commitment to representing disadvantaged groups in politics, including women (Vandeleene, 2014).

Considering the number of women in executive committees, there is a clearer positive evolution over time for all parties, although women also remain underrepresented at an average presence of $39 \%$. The increase in female executive members is most outspoken for N-VA: starting from a significant under-repre- 
Table 2 Women party and executive committee members and party leaders in Flemish local party branches 2006-2018

\begin{tabular}{|c|c|c|c|c|c|c|c|}
\hline & $\begin{array}{l}\text { CD\&V } \\
\text { (\%) }\end{array}$ & $\begin{array}{l}\text { Groen } \\
(\%)\end{array}$ & $\begin{array}{l}\text { N-VA } \\
(\%)\end{array}$ & $\begin{array}{l}\text { Open } \\
\text { VLD } \\
\text { (\%) }\end{array}$ & $\begin{array}{l}\text { Sp.a } \\
(\%)\end{array}$ & $\begin{array}{l}\text { Vlaams } \\
\text { Belang } \\
\text { (\%) }\end{array}$ & $\begin{array}{l}\text { All } \\
\text { parties } \\
\text { (\%) }\end{array}$ \\
\hline \multicolumn{8}{|l|}{2006} \\
\hline Party member $(\mathrm{N}=8 \mathrm{II})$ & 54 & 46 & 36 & 40 & 39 & 31 & 42 \\
\hline $\begin{array}{l}\text { Executive committee mem- } \\
\text { ber }(N=933)\end{array}$ & 36 & 37 & 26 & 35 & 33 & 27 & 35 \\
\hline Party leader $(\mathrm{N}=813)$ & 15 & 17 & 7 & 10 & 9 & 0 & 11 \\
\hline \multicolumn{8}{|l|}{2012} \\
\hline Party member $(\mathrm{N}=454)$ & 43 & 46 & 35 & 39 & 42 & 33 & 40 \\
\hline $\begin{array}{l}\text { Executive committee mem- } \\
\text { ber }(N=815)\end{array}$ & 40 & 41 & 27 & 39 & 37 & 29 & 35 \\
\hline Party leader $(N=799)$ & 17 & 17 & 9 & 20 & 15 & 17 & 15 \\
\hline \multicolumn{8}{|l|}{2018} \\
\hline Party member $(\mathrm{N}=157)$ & 45 & 44 & 36 & 41 & 42 & 34 & 41 \\
\hline $\begin{array}{l}\text { Executive committee mem- } \\
\text { ber }(N=379)\end{array}$ & 41 & 39 & 39 & 40 & 39 & 34 & 39 \\
\hline Party leader $(N=426)$ & 12 & 27 & 7 & 10 & 18 & 21 & 16 \\
\hline
\end{tabular}

sentation (26\%) in 2006, women now make up, on average, 39\% of its executive committee members. Averages in 2018 run around 40\% for most other parties, except Vlaams Belang, which presents (only) 34\% of female executive committee members.

Similarly to the evolution in local electoral politics (see Section 2), the highest position in the local party branch - the leadership of the local party in this case remains dominated by men. On average, $16 \%$ of the local party chairs are women. Groen is the most progressive in this regard, but Vlaams Belang is also doing rather well. The latter is remarkable, since Vlaams Belang had the lowest percentages of women among their members and executive committees. Party ideology again seems to play a role, as the highest number of female party chairs is found among leftist parties.

Also noteworthy is the fact that local party branches chaired by women have higher percentages of women in their membership bases and executive committees, as compared with parties chaired by men. For example, the average percentage of female party members in 2018 increases to $49 \%$, and that of female executive committee members to $44 \%$, when the party leader is female. Based on the available data, it is not possible to indicate the direction in which this interaction should be interpreted. On the one hand, we can assume that female leaders act as some kind of role models and succeed in bringing more women to the party (Franceschet, Krook \& Piscopo, 2012). On the other hand, the better representation of women among the lower echelons of the party can also increase the odds that a woman is elected as chair of a local party branch (either because of the 
Table 3 Recruitment problems identified for male and female candidates (in \%) $(N=423)$

\begin{tabular}{|c|c|c|c|c|c|c|}
\hline Party & $\begin{array}{l}\text { Sex } \\
\text { candi- } \\
\text { date }\end{array}$ & $\begin{array}{l}\text { No prob- } \\
\text { lems (\%) }\end{array}$ & $\begin{array}{l}\text { Lack of } \\
\text { interest } \\
\text { in a } \\
\text { political } \\
\text { career } \\
(\%)\end{array}$ & $\begin{array}{l}\text { Politics } \\
\text { has a bad } \\
\text { name (\%) }\end{array}$ & $\begin{array}{l}\text { Only few } \\
\text { people } \\
\text { recognise } \\
\text { themselves } \\
\text { in the party } \\
(\%)\end{array}$ & $\begin{array}{l}\text { Few candi- } \\
\text { dates } \\
\text { present } \\
\text { themselves } \\
\text { spontane- } \\
\text { ously (\%) }\end{array}$ \\
\hline \multirow[t]{2}{*}{ CD\&V } & $\hat{0}$ & 34 & 8 & 12 & 2 & 15 \\
\hline & q & 17 & 32 & 19 & 4 & 32 \\
\hline \multirow[t]{2}{*}{ Groen } & $\hat{\sigma}$ & 18 & 19 & 16 & 4 & 30 \\
\hline & q & 12 & 31 & 19 & 3 & 35 \\
\hline \multirow[t]{2}{*}{ N-VA } & $\hat{\sigma}$ & 42 & 11 & 8 & 1 & 15 \\
\hline & q & 20 & 38 & 16 & 2 & 38 \\
\hline \multirow[t]{2}{*}{ Open VLD } & $\hat{\sigma}$ & 47 & 17 & 23 & 10 & 20 \\
\hline & q & 23 & 40 & 33 & 17 & 40 \\
\hline \multirow[t]{2}{*}{ Sp.a } & $\hat{0}$ & 31 & 22 & 22 & 15 & 36 \\
\hline & q & 11 & 39 & 31 & 18 & 36 \\
\hline \multirow[t]{2}{*}{ Vlaams Belang } & $\hat{0}$ & 21 & 21 & 18 & 9 & 24 \\
\hline & q & 12 & 32 & 27 & 15 & 35 \\
\hline \multirow[t]{2}{*}{ All parties } & $\hat{\sigma}$ & 32 & 15 & 15 & 6 & 23 \\
\hline & q & 15 & 35 & 23 & 8 & 38 \\
\hline
\end{tabular}

larger supply of female aspirants and/or because of gendered recruitment and advancement patterns in those parties).

The overall rather selective internal feminisation of local party branches, as previously described, is relevant because of the important role local party chairs play in the recruitment and selection of candidates for local electoral politics. The question is whether more feminised local party branches encounter fewer problems attracting women candidates and are more supportive of structural measures to promote gender equality among candidates. In Sections 5 and 6, we tackle these questions consecutively.

\section{Recruitment Practices and Feminisation}

Do local party branches face problems related to the recruitment of (female or male) candidates? Previous studies suggest that parties sometimes consider the search for female candidates to be more difficult than that for male candidates, because the former requires a more active recruitment (Erzeel \& Meier, 2011). In order to examine this issue, local party chairs were asked to indicate what kinds of problems they encounter when recruiting male and female candidates for elections. Table 3 provides an overview of these problems and the extent to which they hold for male and female candidates. 
Table 4 Recruitment problems identified for male and female candidates subgroup analysis (in \%)

\begin{tabular}{|c|c|c|c|c|c|c|c|}
\hline & & $\begin{array}{l}\text { Candi- } \\
\text { date } \\
\text { sex }\end{array}$ & $\begin{array}{l}\text { No } \\
\text { prob- } \\
\text { lems } \\
(\%)\end{array}$ & $\begin{array}{l}\text { Lack of } \\
\text { interest } \\
\text { (\%) }\end{array}$ & $\begin{array}{l}\text { Politics } \\
\text { has a } \\
\text { bad } \\
\text { name } \\
(\%)\end{array}$ & $\begin{array}{l}\text { Few people } \\
\text { recognise } \\
\text { themselves } \\
\text { in the party } \\
(\%)\end{array}$ & $\begin{array}{l}\text { Few candi- } \\
\text { dates } \\
\text { present } \\
\text { themselves } \\
\text { spontane- } \\
\text { ously (\%) }\end{array}$ \\
\hline \multirow[t]{4}{*}{ Party chair } & Male & $\pi$ & 34 & 14 & 16 & 7 & 23 \\
\hline & & q & 16 & 36 & 24 & 9 & 39 \\
\hline & Female & $\hat{0}$ & 23 & 20 & 14 & 3 & 24 \\
\hline & & q & 14 & 29 & 18 & 3 & 30 \\
\hline \multirow{4}{*}{$\begin{array}{l}\text { Female } \\
\text { members }\end{array}$} & $<40 \%$ & $0^{\lambda}$ & 32 & 22 & 19 & 11 & 35 \\
\hline & & q & 15 & 39 & 32 & 13 & 51 \\
\hline & $\geq 40 \%$ & $\hat{0}$ & 42 & 22 & 22 & 8 & 33 \\
\hline & & q & 21 & 47 & 31 & 11 & 42 \\
\hline \multirow{4}{*}{$\begin{array}{l}\text { Women in } \\
\text { executive } \\
\text { committees }\end{array}$} & $<30 \%$ & 0 & 38 & 15 & 17 & 7 & 26 \\
\hline & & $q$ & 14 & 41 & 24 & 10 & 50 \\
\hline & $\geq 30 \%$ & $\hat{0}$ & 34 & 17 & 17 & 7 & 25 \\
\hline & & $q$ & 18 & 37 & 25 & 8 & 38 \\
\hline
\end{tabular}

Table 3 shows that only a small group of respondents indicate that they encounter no problems in the recruitment of candidates. Gender differences exist for the different criteria, and all criteria are seen as more problematic for female than for male candidates. The biggest problems related to the recruitment of female candidates seem to be linked to the supply side, in that few women present themselves spontaneously and there is a lack of interest among women in a political career (note that the survey question does not allow us to grasp whether the latter is just a feeling of local chairs or whether they echo the responses that they receive when recruiting candidates). The two problems are arguably related: as women are not interested in a political career, they will not present themselves spontaneously as candidates. This also means that political parties have to actively search for female candidates.

Looking at the party differences in Table 3, we notice that all parties experience more problems with recruiting female candidates compared with male candidates, although differences are the smallest for Groen. Especially N-VA, Open VLD and Sp.a chairs note a greater lack of interest among women than other parties. $C D \& V$ and N-VA chairs experience more political interest in male candidates and fewer problems with male candidates presenting themselves spontaneously. All in all, however, differences between party families remain small, which means that a left-right ideological divide in gendered recruitment problems cannot be deduced. 
Table 5 Support for binding quota regulations for women adopted by the government or by the national party (in \%)

\begin{tabular}{lll}
\hline & $\begin{array}{l}\text { Quota adopted by the } \\
\text { government (\%) }\end{array}$ & $\begin{array}{l}\text { Quota adopted by the } \\
\text { national party (\%) }\end{array}$ \\
\hline CD\&V & $4 \mathrm{I}$ & 34 \\
Groen & 73 & 57 \\
N-VA & 29 & 22 \\
Open VLD & 33 & 24 \\
Sp.a & 54 & $5 \mathrm{I}$ \\
Vlaams Belang & 10 & 19 \\
All parties & $43 \quad \mathrm{~N}=279$ & $37 \quad \mathrm{~N}=28 \mathrm{I}$ \\
& & \multicolumn{2}{c}{} \\
\hline
\end{tabular}

Further subgroup analyses illustrate that the differences between the political parties are to some extent correlated with the differences in the degree of internal feminisation. As shown in Table 4, male party chairs experience more problems in recruiting female candidates compared with female party chairs. More male than female chairs witness a lack of interest in a political career among women and find that fewer female candidates present themselves spontaneously. This finding indicates that the recruitment of candidates is indeed gendered (Bjarnegård, 2013): female party chairs generally have more women in their networks and are therefore likely to experience fewer difficulties in attracting politically interested women. This might also be explained from an outgroup perspective (Niven, 1998), in which male party elites prefer candidates like themselves. Parties with women in their highest ranks, on the other hand, are more likely to display a higher commitment towards women candidates (Vandeleene, 2014).

Moreover, we see that in parties in which the membership base consists of more than 40 percent of women, the problem of female candidates not spontaneously presenting themselves is less apparent. As membership bases continue to be an important recruitment pool for political parties (Scarrow, 2015), it comes as no surprise that a higher number of female members results in a higher number of female candidates presenting themselves spontaneously. The same holds for political parties with an executive committee consisting of more than $30 \%$ of women.

\section{Structural Measures Promoting Feminisation}

The final part of the analysis focuses on local party chairs' support for, and adoption of, structural measures promoting the (external) feminisation of party politics. We start with party chairs' support for binding quotas for women and make a distinction between party chairs' attitudes towards quota regulations adopted by the government and those adopted by the national party in Table 5 . The findings show that attitudinal support for gender quotas is overall relatively limited 
among local party chairs. Less than half of the group of respondents support binding gender quotas, with this support being slightly higher for quotas adopted by the government (43\%) than for quotas adopted by the national party (37\%). This is an interesting finding for two reasons. First, the results reveal a rather persistent negative attitude towards binding gender quotas expressed by local party chairs. Twenty-five years after the introduction of the first quota acts in Belgium, the majority of local chairs still remain unsupportive of binding gender quotas. Compared with 2006 and 2012, the group of respondents calling into question the necessity of legally gender quotas has decreased for every party family (see Celis et al., 2013 for a comparison). Yet more than half of the group of local party chairs still find gender quotas unnecessary, which implies that the resistance against such structural measures is quite tenacious. Second, and in spite of the previous, local party chairs do have a (slightly) better opinion of quotas adopted by the government than of party quotas. This might indicate that the existence of legally binding gender quotas, as adopted by the Belgian government, has reduced the need identified by parties to have additional party quotas. This is also in line with what previous studies have found in relation to the disappearance of formal rules related to gender in party statutes in recent years (Erzeel, Meier \& Vandeleene, 2018).

Support for quota regulations, moreover, differs between party families, and these differences do seem to overlap with the left-right cleavage. Left-wing parties such as Groen and Sp.a are more prone to supporting binding gender quotas than right-wing parties such as Open VLD, N-VA and Vlaams Belang. The centre party $C D \& V$ holds the middle ground. The largest amount of support for both types of quotas is found among green parties, where $73 \%$ and $57 \%$ of the party chairs support gender quotas adopted by the government and the national party, respectively. The strong support among green parties is in line with previous findings showing that 'new left' parties are front runners when it comes to the promotion of structural measures aimed at gender equality in politics (Kittilson, 2006). The lowest support for such measures is found among Vlaams Belang, where only $10 \%$ of the chairs support government quotas and $19 \%$ support national party quotas.

Finally, we also note that support for both types of quota regulations is related: $73 \%$ of the respondents who are in favour of quota regulations adopted by the government also support quota regulations adopted by the national party; $84 \%$ of the respondents in favour of national party quotas also support legally binding quotas. Respondents do not make a distinction between different types of gender quotas when they express their attitudes towards such structural measures.

Because previous studies have shown that the attitudes of politicians with regard to gender quotas correlate with the degree of feminisation within their party (Kittilson, 2006; Krook, 2009), Table 6 relates respondents' support for binding gender quotas to our three indicators of internal party feminisation: the presence of a female chair, the percentage of female members and the percentage of women in executive committees. The results, first of all, show that the amount of support expressed for gender quotas is different for parties with a male or 
female chair. In parties with a female chair, the respondents give a much more positive evaluation of both government and party quotas. These gender differences persist even after controlling for party family. A substantial presence of female members also plays a role. In parties where more than $40 \%$ of the members are women, respondents express higher levels of support for gender quota regulations than in parties where the share of female members is lower. Differences according to women's presence among party executives exist as well: in parties where the percentage of female executive committee members is higher than $30 \%$, respondents are slightly more likely to adopt a positive attitude towards binding gender quotas than in parties where the percentage remains under $30 \%$. These differences are, nevertheless, small and insignificant. Overall, the results in Table 6 suggest that the degree of feminisation within parties does play a role. In line with earlier research, we find that positive attitudes towards binding gender quotas are more likely to be found in parties that already show a higher degree of party feminisation (Meier \& Verlet, 2008b; Celis et al., 2013).

In addition to their general attitudes towards gender quota regulations, respondents were also asked to indicate the extent to which their parties adopt additional measures to promote gender equality on candidate lists. The Belgian gender quota acts oblige parties to include an equal number of male and female candidates on the entire list and to apply a zipper principle for the first two list positions. However, the order of candidates on the entire list, as well as the presence of women at the top of the list, are not determined by law in Flanders. The survey therefore asked respondents to specify whether they apply a zipper principle on the entire list and whether measures are taken to appoint female head of list candidates. With such initiatives, Flemish parties show their willingness to guarantee a gender balance on candidate lists that go beyond the legal obligations. The question on the application of the zipper principle on the entire list is, furthermore, interesting, because the list zipper principle has been adopted by the Brussels and Walloon governments. Hence, the survey allows us to measure the support among Flemish parties for a similar extension of the parity quotas.

In the 2018 survey, 32\% of the local party branches indicated that they apply a zipper principle on the entire list, and $23 \%$ indicated having taken measures to appoint women at the top of the list (see Table 7). Only $8 \%$ of the party branches combine both. The zipper principle seems, on average, slightly better established than the choice of a female head of list, although this higher average score is partly driven by the fact that a large majority of green local party branches have adopted the zipper principle (73\%). For all other parties, this percentage is much lower; less than one-third of these parties strive for the alternation of women and men on lists. Measures aimed at supporting female head of lists are less prominently present among the different parties. Less than one-fourth of the respondents indicate that their party has taken measures to improve women's presence at the top of the list. Differences between parties are small, and the effect of the left-right cleavage seems to disappear, although Groen stands out as presenting the highest percentage of party branches that have adopted a combination of measures aimed at presenting a female head of list and applying the zipper principle. 
Table 6 Support for binding quota regulations for women - subgroup analysis (in \%)

\begin{tabular}{llll}
\hline & & $\begin{array}{l}\text { Quota adopted by the } \\
\text { government (\%) }\end{array}$ & $\begin{array}{l}\text { Quota adopted by the } \\
\text { national party (\%) }\end{array}$ \\
\hline Party chair & Male & 40 & 34 \\
& Female & 69 & 63 \\
Female members & $<40 \%$ & 34 & 32 \\
& $\geq 40 \%$ & 50 & 40 \\
Women in executive & $<30 \%$ & 41 & 33 \\
committees & $\geq 30 \%$ & 44 & 39 \\
\hline
\end{tabular}

Table 7 Adoption of additional measures to promote gender equality (in \%)

\begin{tabular}{llll}
\hline & Zipper principle (\%) & $\begin{array}{l}\text { Female head of list } \\
(\%)\end{array}$ & Both (\%) \\
\hline CD\&V & 27 & 20 & 10 \\
Groen & 73 & 30 & 21 \\
N-VA & 21 & 25 & 3 \\
Open VLD & 17 & 5 & 0 \\
Sp.a & 28 & 26 & 5 \\
Vlaams Belang & 24 & 24 & 10 \\
All parties & $32(\mathrm{~N}=266)$ & $23(\mathrm{~N}=271)$ & $8(\mathrm{~N}=260)$ \\
\hline
\end{tabular}

Table 8 offers a subgroup analysis of parties' adoption of additional measures to promote gender equality by the level of party feminisation. We note that the application of the zipper principle and measures to support female heads of lists differs between parties with or without a female chair. Parties with a female chair are significantly more likely to apply these additional measures, either separately or in combination, than parties with a male chair. Perhaps surprisingly, and contrary to what previous studies have found for earlier elections in Belgium (Celis et al., 2013) or abroad (Kittilson, 2006), the feminisation of party members and party executives is not (strongly) related to parties' adoption of additional measures. The adoption of the zipper principle is even lower in parties where more women are present in executive committees (29\%) compared with parties where fewer women executive members are present (40\%). This association is, however, not statistically significant in the bivariate analysis.

\section{Conclusion}

The observation that the number of women elected at the local level in Belgium lags behind that characterising the other electoral levels served as the starting point for our analyses. Demand-side factors, particularly the gatekeeping role played by political parties, have so far received the least attention in studies on 
Table 8 Adoption of additional measures to promote gender equality subgroup analysis (in \%)

\begin{tabular}{lllll}
\hline & & $\begin{array}{l}\text { Zipper } \\
\text { principle } \\
(\%)\end{array}$ & $\begin{array}{l}\text { Female } \\
\text { head of list } \\
(\%)\end{array}$ & Both (\%) \\
\hline Party chair & Male & 31 & 19 & 5 \\
& Female & 41 & 50 & 27 \\
Female members & $<40 \%$ & 30 & 25 & 4 \\
& $\geq 40 \%$ & 34 & 24 & 9 \\
Women in executive committees & $<30 \%$ & 40 & 21 & 10 \\
& $\geq 30 \%$ & 29 & 25 & 8 \\
\hline
\end{tabular}

gender and local politics. This article fills this gap by focussing on the 'feminisation' of local party branches (Childs \& Webb, 2011). Feminisation captures the extent to which political parties promote the integration of women in the party. Distinguishing between 'internal' and 'external' feminisation, this article tackles both the integration of women in local party branches (internal feminisation) and their integration as candidates, and, in particular, the existence of rules and practices supporting female candidates in local electoral politics (external feminisation).

In regard to the internal feminisation of Flemish local party branches, a positive evolution over time can be noted, but women remain under-represented in membership bases and executive committees. Also, the leadership of local party branches is almost exclusively in the hands of men. Party ideology seems to be an important denominator in this regard as the highest numbers of female party members, executive committee members and party chairs are found among leftist parties. An increase in the number of women in local electoral politics can be witnessed as well. However, the higher one climbs the ladder of local electoral politics, the lower one finds the number of women to be.

In order to further explore how the internal feminisation of local party branches might help us better understand the external feminisation of local electoral politics, we examined the recruitment problems local party branches encounter and their support for, and adoption of, measures to promote gender equality among candidates.

Our results demonstrate that recruiting candidates comes with challenges. Local party chairs indicate that problems are being faced in regard to the recruitment of candidates and that all criteria are seen as more problematic for female candidates than for male candidates. Local party chairs most notably refer to a lack of interest in a political career among women. This seems to go hand in hand with the level of internal feminisation of the local party branches as male party chairs experience more problems in recruiting female candidates than do female party chairs. This confirms the findings of previous studies that the recruitment of political candidates is a gendered process (Bjarnegård, 2013). 
When it comes to measures taken by local branches to promote gender equality among candidates, support for gender quotas is rather limited among local party chairs, even 25 years after the introduction of the first quota acts in Belgium. Party ideology again seems to play an important role as left-wing parties are more prone to supporting binding gender quotas than right-wing parties. We also witness differences in the amount of support for gender quotas related to the gender of the party chair and the number of female party and executive committee members. These findings indicate that the degree of feminisation within the local branches does play a role in that parties showing a higher degree of (internal) feminisation are more likely to have a positive attitude towards gender quotas.

Looking at the extent to which parties adopt additional measures to promote gender equality on candidates' lists (zipper principle, female head of list), parties show only a limited willingness to go beyond the legal obligations. The zipper principle is found to be slightly better established compared with the choice of a female head of list, but the application of these measures differs between parties with or without a female chair.

Taken together, our results show that processes of internal and external feminisation affect each other. In particular, the gender of the local party chair is found to be very important. The presence of female role models, such as female party chairs, positively affects the recruitment of female candidates. Furthermore, female local chairs are found to be more in favour of binding gender quotas and more likely to adopt additional measures to promote gender equality. This can be linked to the notion of in- and outgroups (Niven, 1998), in which party elites prefer candidates who look like themselves. However, further research is needed to come to a better understanding of the uni- or bidirectional nature of this causal link between internal and external feminisation.

These findings, taken together, further our understanding of how demandside factors shape the political representation of women in local politics and the role played by 'active women' in the party (Kittilson, 2006), such as female party chairs or executive committee members. However, our results also confirm the claims made by recent studies that supply and demand dynamics are in many ways interconnected (Josefsson, 2020; Piscopo \& Kenny, 2020). The problems that party chairs reportedly experience when recruiting and selecting candidates give us a clearer understanding of how local party branches perceive the supply side of the political process and how they eventually perceive male and female candidates differently.

Furthermore, our results highlight that local politics is and continues to be a male-dominated political biotope. Oftentimes, local party branches are seen as training grounds for party members with political ambition (Clark, 2004) or as the most apt to experiment with new forms of political representation and participation (Caluwaerts et al., 2013). The results uncovered here seem to contradict these claims as women continue to encounter major barriers and party chairs are rather reluctant to take more far-reaching measures to foster women's representation. Even though we see an increasing amount of internal feminisation of the Flemish local party branches, this is reflected in the field of local electoral politics 
only to a limited extent. Consequently, the idea of the local level as a lifting mechanism for a career in national politics does not seem to be echoed in reality. To capture what is going on within local branches, and whether resistance and sexism are the root of this problem, requires more in-depth qualitative research.

\section{Notes}

1 Data retrieved from https://igvm-iefh.belgium.be/nl/activiteiten/politiek/cijfers (at 28 November 2019).

2 In that sense, we prefer the use of the term 'external feminisation' rather than 'descriptive representation' because the latter mainly refers to women's numerical representation in politics, whereas the former also includes measurements of parties' support for, and application of, measures to redress women's under-representation.

3 The survey question was the following: Did your party encounter one or more of the following problems in its search for suitable candidates? We distinguish between male and female candidates. If your party did not experience any problems, you may indicate that.

4 The survey questions were the following: "In some cases, the government imposes binding quotas. Do you think this is or would be justified for the following groups: women" (answer: yes/no); "Do you think the national party leadership may impose binding quotas for: women?" (answer: yes/no).

5 The survey question was the following: "Do agreements exist within your local party branch regarding [the pursuit of] a gender balance that go beyond the obligations imposed by the government?" (answer: yes/no).

\section{References}

Bjarnegård, E. (2013). Gender, informal institutions and political recruitment: Explaining male dominance in parliamentary representation. Basingstoke: Palgrave Macmillan.

Briggs, J. (2000). 'What's in it for women?' The motivations, expectations and experiences of female local councillors in Montreal, Canada, and Hull, England. Local Government Studies, 26(4), 71-84.

Buelens, J., Rihoux, B. \& Deschouwer, K. (2008). Tussen kiezer en hoofdkwartier: de lokale partijafdelingen en de gemeenteraadsverkiezingen van 2006. Brussels: ASP.

Caluwaerts, D., Reuchamps, M. \& Brans, M. (2013). Van macht naar massa: burgerparticipatie op het locale niveau. In K. Deschouwer, T. Verthé \& B. Rihoux (Eds.), Op zoek naar de kiezers. Lokale partijafdelingen en de gemeenteraadsverkiezingen van oktober 2012 (pp. 219-241). Brussels: Academic and Scientific Publishers.

Carroll, S. \& Sanbonmatsu, K. (2010). Entering the mayor's office: Women's decisions to run for municipal office. Paper presented at the Annual Meeting of the Midwest Political Science Association. Chicago, April 2010.

Celis, K., Erzeel, S. \& Meier, P. (2013). Twintig jaar quota en wat nu? Een empirische reflectie op de tijdelijkheid van genderquota in de lokale politiek. In K. Deschouwer, T. Verthé \& B. Rihoux (Eds.), Op zoek naar de kiezers. Lokale partijafdelingen en de gemeenteraadsverkiezingen van oktober 2012 (pp. 123-145). Brussels: Academic and Scientific Publishers. 
Childs, S. \& Lovenduski, J. (2013). Political representation. In G. Waylen et al. (Eds.), The Oxford handbook of gender and politics (pp. 489-513). Oxford: Oxford University Press.

Childs, S. \& Webb, P. (2011). Sex, gender, and the conservative party. From iron lady to kitten heels. New York: Palgrave.

Clark, A. (2004). The continued relevance of local parties in representative democracies. Politics, 24(1), 35-45.

Dahlerup, D. (1988). From a small to a large minority: Women in Scandinavian politics. Scandinavian Political Studies, 11(4), 275-298.

Deschouwer, K., Verthé, T. \& Rihoux, B. (2013). Op zoek naar de kiezers. Lokale partijafdelingen en de gemeenteraadsverkiezingen van oktober 2012. Brussels: ASP.

Emery, L., Meier, P. \& Mortelmans, D. (2018). Juggling three life spheres: Reconciling work, family and politics. Community, Work \& Family, 21(2), 226-242.

Erzeel, S. \& Celis, K. (2016). Political parties, ideology and the substantive representation of women. Party Politics, 22(5): 576-586.

Erzeel, S. \& Meier, P. (2011). Is er iets veranderd? De rekrutering en selectie van kandidaten door Belgische partijen na de invoering van quotawetten. Tijdschrift voor Genderstudies, 14(2), 6-19.

Erzeel, S., Meier, P. \& Vandeleene, A. (2018). 25 years of gender quotas and still a man's world. What's wrong with their implementation in the Belgian case? Paper presented at the ECPR General Conference, Hamburg, August 2018.

Franceschet, S., Krook, M. L. \& Piscopo, J. (Eds.). (2012). The impact of gender quotas. New York: Oxford University Press.

Hedlund, G. (1988). Women's interests in local politics. In K. B. Jones \& A. G. Jonasdottir (Eds.), The political interests of gender: Developing theory and research with a feminist face (pp. 79-105). London: Sage.

Holli, A. M. (2011). Transforming local politics? The impact of gender quotas in Finland. In B. Pini \& P. McDonald (Eds.), Women and representation in local government. International case studies (pp. 142-158). Oxford: Routledge.

IGVM. (2019). Aanwezigheid van vrouwen in de Belgische wetgevende en uitvoerende instellingen. Retrieved from https://igvm-iefh.belgium.be/nl/activiteiten/politiek/ cijfers.

Johansson, V. (2006). Gendered roads to mayorship in different welfare states. In H. Bäck, H. Heinelt \& A. Magnier (Eds.), The European Mayor. Political leaders in the changing context of local democracy (pp. 99-120). Wiesbaden: Verlag für Sozialwissenschaften.

Johansson Sevä, I. \& Öun, I. (2019). Conditional representation: Gendered experiences of combining work and family among local politicians. Journal of Women, Politics \& Policy, 40(3), 367-384.

Josefsson, C. (2020). How candidate selection structures and genders political ambition: Illustrations from Uruguay. European Journal of Politics and Gender, 3(1): 61-78.

Kittilson, M. C. (2006). Challenging parties, changing parliaments. Women and elected office in contemporary Western Europe. Columbus: Ohio State University Press.

Krook, M. L. (2009). Quotas for women in politics. New York: Oxford University Press.

Lawless, J. \& Fox, R. (2010). It still takes a candidate: Why women don't run for office. Cambridge: Cambridge University Press.

Leyenaar, M. (2004). Political empowerment of women: The Netherlands and other countries. Amsterdam: Springer-Science.

Magin, R. (2011). Women in local assemblies - rare guests or (almost) equal partners? In B. Pini \& P. McDonald (Eds.), Women and representation in local government. International case studies (pp. 37-55). Oxford: Routledge. 
Meier, P. (2007). Een vergelijkend perspectief op de positie van mannen en vrouwen in de lokale politiek. Res Publica, 49(1),46-64.

Meier, P. (2008). A gender gap not closed by quotas: The renegotiation of the public sphere. International Feminist Journal of Politics, 10(3), 329-347.

Meier, P. (2012). Belgium: The collateral damage of electoral system design. In M. Tremblay (Ed.), Women and legislative representation: Electoral systems, political parties and sex quotas (pp. 143-153). New York: Palgrave Macmillan.

Meier, P. \& Verlet, D. (2008a). Diversiteit troef? Het belang van maatschappelijke groepen bij lokale verkiezingen. In J. Buelens, B. Rihoux \& K. Deschouwer (Eds.), Tussen kiezer en hoofdkwartier. De lokale partijafdelingen en de gemeenteraadsverkiezingen van 2006 (pp. 73-94). Brussels: VUBpress.

Meier, P. \& Verlet, D. (2008b). La position des femmes en politique locale belge et l'impact des quotas. Swiss Political Science Review, 14(4),715-740.

Meier, P. \& Verlet, D. (2011). How gender shapes local party politics: The Case of Belgium, In B. Pini \& P. McDonald (Eds.), Women and representation in local government. International case studies (pp. 115-128). Oxford: Routledge.

Mügge, L., Runderkamp, Z. \& Kranendonk, M. (2019). Op weg naar een betere $\mathrm{m} / \mathrm{v}$-balans in politiek en bestuur. Amsterdam: Universiteit van Amsterdam/Ministerie van Binnenlandse Zaken en Koninkrijksrelaties.

Murray, R. (2015). What makes a good politician? Reassessing the criteria used for political recruitment. Politics \& Gender, 11(4), 770-776.

Niven, D. (1998). Party elites and women candidates: The shape of bias. Women \& Politics, 19(2), 57-80.

Norris, P. \& Lovenduski, J. (Eds.). (1993a). Gender and party politics. London: Sage.

Norris, P. \& Lovenduski, J. (1993b). 'If only more candidates came forward': Supply-side explanations of candidate selection in Britain. British Journal of Political Science, 23(3), 373-408.

Oldersma, J. (2002). More women or more feminists in politics? Acta Politica, 37(3), 283-317.

Pini, B. (2007). Men, masculinities and the (re)gendering of local government in rural Australia. Research in Rural Sociology and Development, 13, 299-315.

Pini, B. \& McDonald, P. (Eds.). (2011). Women and representation in local government. International case studies. Oxford: Routledge.

Piscopo, J. \& Kenny, M. (2020). Rethinking the ambition gap: Gender and candidate emergence in comparative perspective. European Journal of Politics and Gender, 3(1), 3-10.

Ransford, P. \& Thomson, M. (2011). Moving through the pipeline: Women's representation in municipal government in the New England region of the United States. In B. Pini \& P. McDonald (Eds.), Women and representation in local government. International case studies (pp. 21-36). Oxford: Routledge.

Scarrow, S. E. (2015). Beyond party members. New York: Oxford University Press.

Sliwa, S., Meier, P. \& Thijssen, P. (2011). De impact van party magnitude op het aantal vrouwelijke verkozenen. Gender quota in België kritisch bekeken. Res Publica, 53(2), 141-165.

Smith, A. R., Reingold, B. \& Owens, M. L. (2012). The political determinants of women's descriptive representation in cities. Political Research Quarterly, 65(2), 315-329.

Sundström, A. \& Stockemer, D. (2015). What determines women's political representation at the local level? A fine-grained analysis of the European regions. International Journal of Comparative Sociology, 56(2-3), 254-274.

Vandeleene, A. (2014). Gender quotas and 'women-friendly' candidate selection: Evidence from Belgium. Representation, 50(3), 337-349. 
Wauters, B., Otjes, S. \& van Haute, E. (2020). Parties at the grassroots: Local party branches in the Low Countries. Politics of the Low Countries, 2(2). 